\title{
The Role of Strategic Intelligence in Enhancing Effective Talent Management: A Study on some Academic Institutions of Duhok Governorate
}

\author{
Araz Albarwari Sheri'1, Nazar Rasheed Nori², Sandeep Kumar Gupta ${ }^{3}$ \\ 1Technical College of Administration, Business Administration Department, Duhok Polytechnic University, \\ Duhok, Kurdistan Iraq \\ 2Technical College of Administration, Accounting Techniques Department, Duhok Polytechnic University, \\ Duhok, Kurdistan-Iraq \\ ${ }^{3}$ Head Innovation, College of Engineering (Dr APJ Abdul Kalam Technical University), Greater Noida, India
}

\begin{abstract}
This paper seeks to illustrate the role of strategic intelligence in enhancing effective talent management (TM) in academic institutions of Duhok governorate. by identifying research's major problem, which impacts strategic intelligence in enhancing talent management effectiveness in academic institutions in Duhok city? The researchers relied on its both hypotheses. The first one there is a significant relationship between strategic intelligence and effective talent management. The second is strategic intelligence has a positive impact on talent management in the academic institutions of Duhok Governorate. A questionnaire describing strategic intelligence and talent management was designed, distributed, and statistically analyzed using correlation coefficient and linear regression equation to test the research hypothesis validity. The research found that strategic intelligence affects the enhancement of talent management. The study also recommends the tested organizations to pay close and constant attention to strengthening administrative structures and teaching staff in terms of critical thinking, resourcefulness, and strategic intelligence).
\end{abstract}

KEYWORDS: : Strategic Intelligence; Talent Management; Academic Institution; Academic Staff; Duhok Governorate.

\section{Introduction}

The world has witnessed rapid changes in various areas, especially in the last decade of the twentieth century. Such transformations have brought about marked effects on the administrative practices in various organizations. In parallel to that, internal and external challenges, including technological and information developments, have been faced by these organizations. Therefore, this has necessitated upgrading the means to go beyond survival to go into organizational competition. Moreover, organizations have begun to pay attention to strategic leaders who can help them meet the challenges. Strategic intelligence comes at the forefront of mental factors that empower modern organizations to achieve their strategic goals (Nori, 2015) . Intelligent leaders can develop human talents to put in outstanding performance based on creativity and innovation models, human inclusion, and awareness of its mission. Most academic institutions in the city of Duhok are newly established, requiring strategic leaders who can discover talented and distinguished human resources, administrators, and professors to keep up with the recent remarkable developments and educational competition.

\subsection{Research Problem}

Having visionary leadership, effective talent management, and competitive orientation are modern academic institutions' priorities. Delegation of managerial authority is a major challenge that requires adopting appropriate strategies and scenarios to solve daily and future institutional work problems. Strategic intelligence and talent management are vital in addressing these challenges, as formulated in the following question: 
What is the impact of strategic intelligence on enhancing effective talent management among a sample of academic staff in some academic institutions of Duhok Governorate?

\subsection{Research objectives}

- Determine the level of strategic intelligence in the selected institutions.

- Know the extent of interest in talent management in the selected institutions.

- Examine the relation between strategic intelligence and talent management.

- Investigate the effect of strategic intelligence in increasing effective talent management in the selected institutions.

\subsection{Significance of the Study}

The study attempts to assess the correlation between strategic intelligence and talent management (TM). It regards academic institutions as means for the development of modern societies. Talent management is believed to promote academic institutions, consistent human resources performance, and personnel potentials.

\subsection{Research Hypotheses}

- H1: There is a significant relationship between strategic intelligence and effective talent management in Academic Institutions in Duhok city.

- H1A: There is a significant relationship between foresight and effective talent management.

- H1B: There is a significant relationship between systems thinking and effective talent management.

- H1C: There is a significant relationship between future vision and effective talent management.

- H1D: There is a significant relationship between motivation and effective talent management.

- H1E: There is a significant relationship between partnership and effective talent management.

- H2: Strategic intelligence has a significant impact on effective talent management in academic institutions in Duhok in the researched organizations.

- H2A: Foresight has a significant impact on effective talent management.

- H2B: Systems thinking has a significant impact on effective talent management.

- H2C: Future vision has a significant impact on effective talent management.

- H2D: Motivation has a significant impact on effective talent management.

- H2E: Partnership has a significant impact on effective talent management.

\subsection{Research Framework}

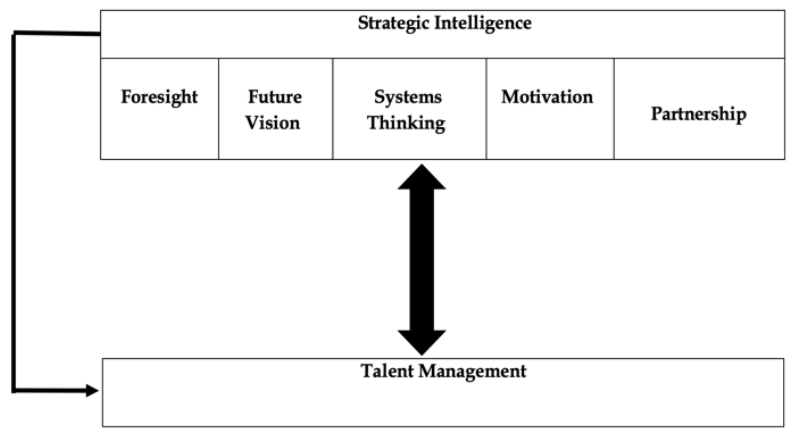

Source: Prepared by researchers

Figure 1: Research Framework

\section{Theoretical Framework}

This literature review starts to introduce the concept of strategic intelligence (SI), move down to the field of talent management, and end by combining the advantage of the two theses fields by evaluating SI ${ }^{\text {ee }}$ role in decision making and their influence on talent management to create a framework for the study.

\subsection{Strategic Intelligence}

Competitive Intelligence (CI) is defined as knowledge about the general environment of the organization. The CI aims to create the desirable business information into actionable form and making it obtainable in time to facilitate proactive decision-making (Maccoby, 2011,58). Strategic intelligence (SI) is an essential tool in involving the strategic management activities in different stages of strategy development. In short, Strategic 
Intelligence can be defined as "the specific form of analysis which is required for the formulation of policy and plans at agency, corporate, national or international levels"(McDowell, 2008, 10). Strategic intelligence aims to collect and analyze data that help to make decisions on a strategic level. Also, to predict and understand where the organization will be in the upcoming years and assist them in facing future challenges. (Fernández-Villacañas, 2015, 3). the following is a table of some of the most important of these views:

Table 1: Some of the Most Important Concepts of Strategic Intelligence

\begin{tabular}{|c|c|c|}
\hline No. & $\begin{array}{l}\text { Author, Year, } \\
\text { Page number }\end{array}$ & The concept \\
\hline 1 & $\begin{array}{l}\text { Kuhlmann et al., } \\
\text { 1999:14 }\end{array}$ & $\begin{array}{l}\text { Creating road maps that direct } \\
\text { decision-makers to make the } \\
\text { right decisions promptly } \\
\text { provides information with the } \\
\text { required quality, accuracy, and } \\
\text { quantity. }\end{array}$ \\
\hline 2 & Quarmby,2003:3 & $\begin{array}{l}\text { It is the intelligence that a } \\
\text { certain level of managers has to } \\
\text { formulate the organization's } \\
\text { long-term strategic policies } \\
\text { and plans. }\end{array}$ \\
\hline 3 & $\begin{array}{l}\text { Sharfman, } \\
2004: 4\end{array}$ & $\begin{array}{l}\text { The process of reviewing the } \\
\text { massive number of data comes } \\
\text { from different sources to link a } \\
\text { small number of these data to } \\
\text { serve the organization's goals. }\end{array}$ \\
\hline 4 & Service,2006: 61 & $\begin{array}{l}\text { It can develop appropriate } \\
\text { strategies to address future } \\
\text { environmental impacts, and } \\
\text { this intelligence includes } \\
\text { talent, understanding, } \\
\text { knowledge, flexibility, and } \\
\text { expansive imagination. }\end{array}$ \\
\hline 5 & $\begin{array}{l}\text { Clar et al., 2008: } \\
2\end{array}$ & $\begin{array}{l}\text { A group of operations that } \\
\text { seek to find and process } \\
\text { information, then publish and } \\
\text { protect it, in order to make it } \\
\text { available to the right } \\
\text { individual at the right time to } \\
\text { enable them to make the right } \\
\text { decision }\end{array}$ \\
\hline 6 & $\begin{array}{l}\text { Fernández- } \\
\text { Villacañas, 2015: } \\
3\end{array}$ & $\begin{array}{l}\text { "Organization designed to } \\
\text { collect information } \\
\text { transforming into a useful } \\
\text { product for decision making }\end{array}$ \\
\hline
\end{tabular}

for a user to solve a current or future situation."

Source: Prepared by the researchers based on the above references.

From the preceding, a concept of strategic intelligence can be presented as one of the components of the strategic mind that interacts with its components such as awareness, thinking, and strategic learning, and it is an intangible resource that constitutes a source of strategic strength for the leadership of the organization.

\subsubsection{Dimensions of Strategic Intelligence}

There are five dimensions to identify how thinking strategically can be beneficial to our business. (Al-Nuaimi, 2008, 173) and (Maccoby, 2001, 58-59).

- Foresight: it is the ability to realize current and emerging trends that introduces threats or opportunities for an organization;

- Visioning or future vision: the ability to design an ideal future state relying on foresight dimension and create a process to persuade others to perform it;

- Systems thinking: the ability to produce, synthesize, and integrate elements rather than breaking them into a part for the analysis that function as a whole to achieve a common purpose.

- Motivation: The ability to inspire different people to embrace a common goal, to implement a vision. Understanding what motivates people is on upon another ability, personality intelligence.

- Partnership: the ability to develop strategic alliances with individuals, groups, and organizations. This quality also depends on personality intelligence.

\subsubsection{Strategic Intelligence Stages}

According to Fleisher \& Bensoussan (2015); Tham \& Kim (2002); \& Xu (2007) the Intelligent agent cycle consists of the following five stages: 
- Plan: the main aims of this stage is to determine client needs, launching requirements, and developing a plan.

- Collect and process data: this step is responsible for collecting and processing data.

- In this stage, data is collected from inside and outside the firm, and the primary classification of the collected data and data reductions are implemented.

- Analysis: The analysis task is performed in this stage

- Discriminate Intelligence: this the stage where intelligence is disseminated. Then, the generated insights are provided to the customer.

- Evaluate and control: evaluating and controlling the process are done in the final stage. This can be achieved by collecting feedback and assessing whether the process has fulfilled the client's needs and possibly restarts if it has failed to.

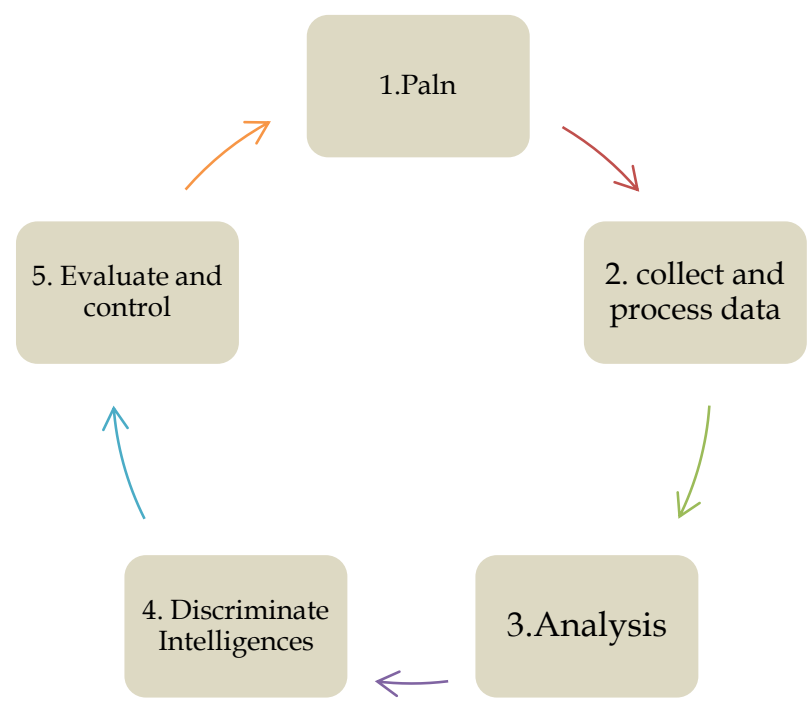

Source: Fleisher \& Bensoussan ,2015, 11

Figure (2): Strategic Intelligence Cycle

\subsection{Talent Management}

Due to demographic developments, growing numbers of organizations globally, and enhancement in technology, the number of qualified career starters is declined rapidly. Therefore, it is crucial for companies to make the right decisions while selecting their employees to be well placed in the future time. Hence, Talent Management is one of the best success criteria for private and public organizations.

It is hard to identify talent management's exact meaning because of the confusion concerning definitions made by authors who write about talent management. The terms talent management, "succession management," "talent strategy," and "human resource planning" are often used interchangeably ( Lewis \& Heckman, 2006, 140) Consider, for instance, the following statements concerning processes for requiring people in organizations: ensure right person at the right time for the right reasons (Jackson \& Schuler, 1990, 235); “The implementation of integrated strategies or systems designed to increase workplace productivity by developing improved processes for attracting, developing, retaining and utilizing people with the required skills and aptitude to meet current and future business needs." (Fegley, 2006, 1). According to (Armstrong, 2009, 168), talent management ensures that the organizations anticipate and meet their needs of talented and high qualified individuals to achieve organizational goals. TM: Focus on highly skilled people who can make a difference in their performance through their contribution. (Stredwick, 2013, 315).

The concept of talent management can be explained as a set of activities assigned to strategies that enable it to attract talented human resources with capabilities, competencies, skills, and initiatives distinct from others, in addition to enabling them to develop their talents, especially leadership, to assume sensitive positions and maintain them for as long as possible, which help them to achieve an outstanding performance that is unique to competitors (AlMarakhi \& Mahmoud 2018, 856).

Based on the above, researchers can provide a procedural concept for talent management:

It is a process of adopting a strategic vision of what the organization's talents will be in the future and 
embodying it with a clear and sincere message to the organization's human resources to foster complete faith in the importance of discovering, attracting, and maintaining talents as it is the capital of the organization capable of successfully achieving its primary goals. Moreover, talent management can be described as the methodically organized, strategic process of getting attract, retain and engage talented employees on board and helping them develop their optimum skills remaining organizational objectives in their mind.

\subsubsection{Need for talents}

Organizations need to announce talent management due to the several factors which are discussed in the following points:

- Globalization is one of the important factors because it is a growing interdependence of the world's economies, cultures, and populations, even in labor. For this reason, labors are no longer limited to promoting their capabilities only inside one market. Besides, Many companies are offshoring their manufacturing, IT departments, callcenters, finance, and accounting departments to another country to take advantage of reduced labor costs (Tucker, et al., 2005, 18).

- Increasing longevity and declining fertility rates lead to a decrease in the size of the industry's working-age population (Tucker, et al., 2005, 19).

- Global competition for skilled workers is also a matter of concern; if the worker did not improve their capabilities, they would be less likely to get the job (Antonucci, 2005, 6).

- Finally, the impact on skills shortages. For example, in South Africa, employees do not have sufficient Information and Communication Technology (ICT ) skills to apply for the job due to their education system (James, et al. , 2001 ). For this reason, the organization will continue a considerable effort to find, attract and retain talented employees in the ICT sector.

\subsubsection{The process of talent management}

Armstrong (2014, 267-268); Hughes \& Rog (2008, 745); Grobler \& Diedericks (2009, 15-16); Tetik (2017, 47).

- Talent planning: is the first step of the TM process, which means organizations should determine the number of talented employees and specify their skills and requirements for the present and future.

- $\quad$ Resourcing: The outcome from the previous step means the organizations should have programs for catching and getting employees inside and outside the institution. If organizations can develop existing employees, it does not need to hire new ones.

- Talent identification: searching for those employees who are eligible to participate in career and development programs. The performance management system can identify employees with abilities and potential.

- Talent relationship management: Build, create and develop a relationship with potential talent. An existing relationship is better to be built rather than creating a new one. The aim is to recognizing employee's value, treating them fairly, providing growth opportunities.

- Talent development: The potential components for developing talent is learning and development programs and policies. Talent development focuses on how organizations develop staff skills and competencies.

- Talent retention: This is all the activities and practices utilized by institutions to avoid talent turnover. Organizations should design policies and implement them to ensure that high-quality employees remain committed members of the organization.

- Career management: Is the process for enabling people to develop their competencies, abilities, and career skills, "and ensuring that the organization has the flow of talent it needs." 
- Management succession planning: the aim is to know that the institution has the managers it requires to meet future needs. It focuses on identifying capable managers to fill vacant managerial positions in the future.

- The talent pipeline: "The processes of resourcing, talent development, and career planning that maintain the flow of talent needed to create the talent pool required by the organization."

- The talent pool: Is a group of highly skilled employees within an organization who will be candidates for potential positions.

This process is shown in the below figure.

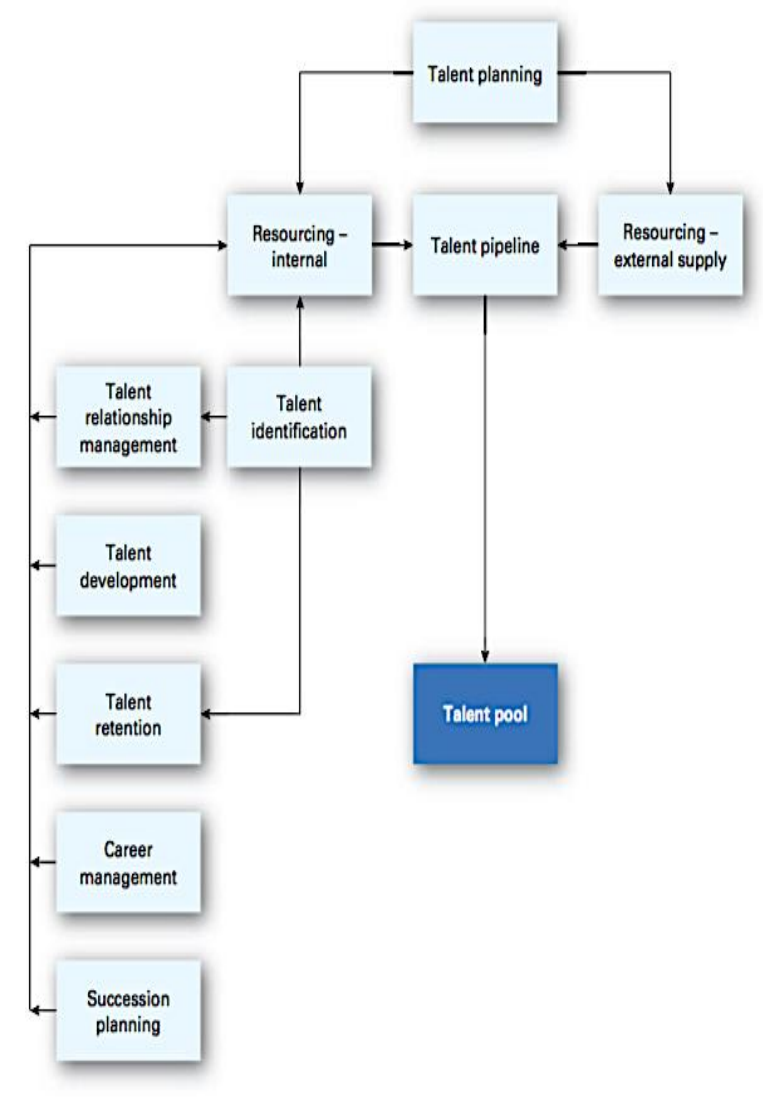

Figure (3): The Process of Talent Management

Adapted from Armstrong, 2014, 268

\subsubsection{Significance of Talent Management}

TM emerged in the late 1990s, which drives by the phrase "the war for talent." It was improve the processes of attracting and developing talented individuals to be in line with the needs and requirements of organizations. (Aston \& Morton 2005: $704)$ in their research tagged talent management to achieve a competitive advantage indicated that talent management is an administration of strategic importance and it helps to achieve excellence in the performance of the organizations' work, and what is noted in the importance of talent management is that it focuses on individuals with the perceived importance of intangible resources in the knowledge economy, and the remarkable lack of administrative talent and pressure for the competition had a significant impact on increasing the importance of managing talent. (Al-Jumaili 2013, 43) and (Bader \& Lasprilla, 2009, 3) pointed out that talent management is the basis for organizations' success, creativity, and excellence, and the basis for their development, and organizations that seek success and interest in this rare resource must maintain it to obtain a sustainable competitive advantage and thus we can say the talent management is as follows:

- Hold positions with suitable people with unique capabilities, knowledge, and high performance.

- Promote high potentials to increase its impact on the organization's productivity.

- Work to develop employees and improve their competencies in their current and future work.

- Improve performance by preserving the talented employees.

Researchers believe that talent management plays a prominent role in making organizations with a strong competitive position and have a large market share because of the distinguished management of talented human resources and act as the market leader for the competing organizations.

2.3 Relation between Strategic Intelligence and Effective Talent Management

Strategic intelligence, with its main dimensions such as motivation, strategic vision, systems thinking, foresight, and partnership, are the basics of excellence, an essential factor for every manager in successful strategic planning. Therefore in the process of successful talent management towards attracting, 
retaining, and developing talents to work on attaining the main goals, the achievement of this is based on a level of the manager's high strategic intelligence, which is the vital premise for achieving talent management, achieving its various objectives with distinction and excellence.

\subsection{Previous Studies}

The researchers found a need to review some studies that dealt with research variables in addressing the problems facing organizations. The requirements for their solutions are related to strategic intelligence and talent management. The best study to benefit from is (Nori, 2015) and (Freidberg \& Kao, 2008). Besides, there are other studies shown in table (2).

Table (2): basic details from previous studies

\begin{tabular}{|c|c|c|c|}
\hline $\begin{array}{l}\text { The } \\
\text { Arthu } \\
\text { r }\end{array}$ & Year & $\begin{array}{l}\text { Research } \\
\text { problem }\end{array}$ & $\begin{array}{l}\text { Research } \\
\text { objective }\end{array}$ \\
\hline Yusof & 2013 & $\begin{array}{l}\text { The What is the } \\
\text { mechanism of role of } \\
\text { alertness and alertness } \\
\text { strategic and } \\
\text { intelligence is intelligence } \\
\text { a tool to face in facing } \\
\text { future the future i } \\
\text { challenges challenges } \\
\text { and one of the of Algerian } \mathrm{f} \\
\text { factors of economic } \\
\text { competitivene institutions } \\
\text { ss ? }\end{array}$ & $\begin{array}{l}\text { Both alertness } \\
\text { and strategic } \\
\text { Explaining intelligence play } \\
\text { the extent of an important role } \\
\text { the role that in helping the } \\
\text { alertness and departments of } \\
\text { strategic economic } \\
\text { intelligence institutions solve } \\
\text { play in their problems } \\
\text { facing future resulting from } \\
\text { challenges future } \\
\text { environmental } \\
\text { changes. }\end{array}$ \\
\hline Nori & 2015 & $\begin{array}{l}\text { What is the } \mathrm{i} \\
\text { The effect of impact of } \\
\text { strategic strategic } \\
\text { intelligence on intelligence } \\
\text { the on the } \\
\text { distinguished outstandin } \\
\text { performance g } \\
\text { of human performanc } \\
\text { resources e of human r } \\
\end{array}$ & $\begin{array}{l}\text { Identify the } \\
\text { impact of } \\
\text { strategic Strategic } \\
\text { intelligence intelligence plays } \\
\text { on the a significant role } \\
\text { distinguishe in achieving the } \\
d \\
\text { performance outstanding } \\
\text { of human performance of } \\
\text { resources in human resources } \\
\text { the research } \\
\text { sample }\end{array}$ \\
\hline $\begin{array}{l}\text { Freid } \\
\text { berg } \\
\& \text { Kao }\end{array}$ & 2008 & 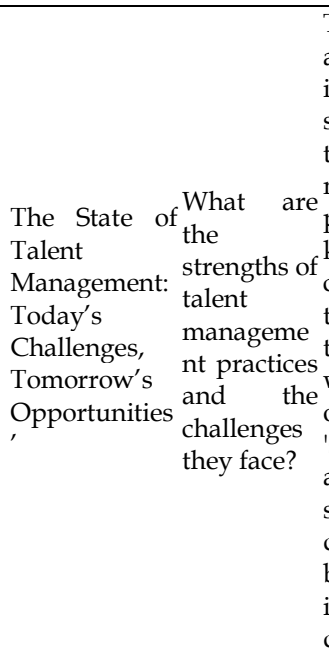 & $\begin{array}{l}\text { The study } \\
\text { aimed to } \\
\text { identify the } \\
\text { strengths of The development } \\
\text { talent in talent } \\
\text { management management } \\
\text { practices and causes } \\
\text { know the innovative } \\
\text { challenges practices in the } \\
\text { they face and selected } \\
\text { the extent to companies and } \\
\text { which the that the quality of } \\
\text { organization talent is a } \\
\text { 's practices sustainable } \\
\text { are competitive } \\
\text { sophisticate advantage. } \\
\text { d as they can } \\
\text { be well } \\
\text { implemente } \\
\text { d. }\end{array}$ \\
\hline
\end{tabular}

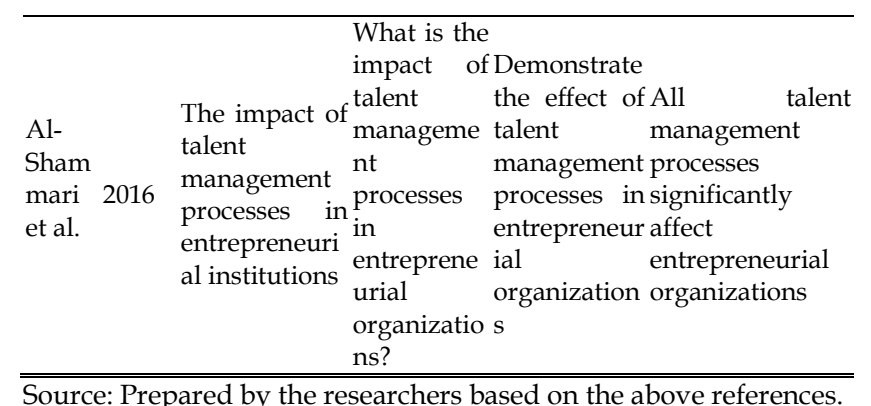

Based on what is presented in Table (2), the current research can be compared to previous studies and according to the table's axes. The current research has dealt with strategic intelligence's role in enhancing effective talent management, a study on a sample of department heads in some academic institutions in Duhok city. We note that it differs from the above studies in terms of the problem. The objectives, as the problem of the current research, was to determine the relationship between strategic intelligence as an independent variable and the extent of its influence in boosting effective talent management as a dependent variable, and this is what we did not find in previous studies as most of them dealt with them separately with other variables and did not combine the two variables. The current research also differs from the studies shown in table (2) in reaching the main conclusion: the correlation between strategic intelligence and talent management is significant, and strategic intelligence has a significant impact on talent management.

\section{Research Methodology}

\subsection{Population and Research Sample}

Some academic institutions in the city of Duhok as a research population are (Duhok Polytechnic University, University of Duhok, and Cihan University). A sample of research with characteristics based on academic staff occupies a position as head of the scientific department. The online questionnaires were sent to academic staff by email and via social networks such as Viber and WhatsApp. The number of the questionnaire was distributed according to the number of scientific departments which counts 50 
forms. Therefore, there is a variation in the questionnaires distributed to the research population. Fewer questionnaires were distributed to heads of scientific departments at Cihan University, while an enormous volume of questionnaires was sent to Duhok Polytechnic University and the University of Duhok.

\subsection{Validity and Consistency of the Questionnaire}

The researchers see the necessity of showing the extent of the validity of the questionnaire, as it is the primary source in obtaining information from the sample members, that the integrity of the questions, the quality of their formulation, their consistency with each other, and their consistency with the research variables is an indication of the reliability and consistency of the questionnaire and to be a useful tool to visualize the field reality of the research problem and provide reliable results on the validity of the research hypotheses.

Therefore, the researchers initially relied on showing the extent of consistency and correlation of the questions with each other through the use of the Pearson correlation coefficient and the correlation matrix that the indicators of the independent variable (Strategic Intelligence), which are represented by questions that start from $\mathrm{X} 1$ to $\mathrm{X} 15$ with the indicators of the depended variable (talent management), which is represented by questions that start with X16 to X24, most of them are related to a positive relationship. It is a significant indication of the validity and integrity of the internal consistency of the questionnaire questions. Additionally, researchers relied on previous studies for designing questionnaires, particularly those mentioned in section 2.4 in this paper.

The researchers also used the response index for the individuals of the sample as a second means to support the extent of validity and consistency of the questionnaire, where the questionnaire was distributed electronically to the members of the sample and the total number reached 50 forms, 47 complete forms were retrieved from them without any deficiency despite the Coronavirus (Covid19) health crisis that everyone was suffering from. The response was strong and reached $94 \%$. It is another indicator that supports the validity and integrity of the questionnaire.

\section{Data analysis and Results}

\subsection{Description of some of the personal characteristics of the research sample}

The results from table (3) show that most respondents are male; from the 47 respondents, 42 are male, which represents $89.4 \%$, and the remaining 5 are female with a percentage of $10.6 \%$. This indicates that there is no gender balance at the head of department position in the sampled Universities. The study found out that most of the respondents were between (31-40) years and the percentage was $53.2 \%$, followed by the age group (41-50), which has reached 34\%, those aged less than 30 and more than 51 years have equal proportion which is only $6.4 \%$ for each of them. The results illustrated that academic staff (head of departments) with a master's degree have a majority of 70\%, followed by those with a PhD degree, where they accounted for $27 \%$. In contrast, individuals with a bachelor's degree in education have attained the lowest possible degree, only $2 \%$. This indicates that the universities rely more on academic staff with a master's degree in managing scientific departments because of the lack of PhD holders, especially in Duhok Polytechnic University. It almost does not depend much on staff with a bachelor's degree in managing that position. The results also show that individuals who have (11-20) years of experience at the university reached $57.4 \%, 38.3 \%$ maintained less than years of work experience. The remaining percent is 4.2 for those who have more than 21 years of experience. Finally, the results illustrate that the highest percentage of the head of departments are those who have between 2-4 years of experience at that position, which is $46.8 \%$, academic staff which has less than 2 
years of experience at managing departments reached $36.2 \%$, and the remained proportion was to 5-8. Those exceeded 8 years, which represent 10.6 and 6.4, respectively.

Table (3): Descriptive Analysis

\begin{tabular}{lll}
\hline \hline Descriptive & Frequency & percentage \\
\hline Gender & & \\
\hline Male & 42 & 89.4 \\
\hline Female & 5 & 10.6 \\
\hline Age (years) & & \\
\hline less than 30 years & 3 & 6.4 \\
\hline 31-40 & 25 & 53.2 \\
\hline 41-50 & 16 & 34.0 \\
\hline 51 years and more & 3 & 6.4 \\
\hline Education Level & & \\
\hline BSc & 1 & 2.1 \\
\hline MSc & 33 & 70.2 \\
\hline PhD & 13 & 27.7 \\
\hline Work Experience (years) & & 38.3 \\
\hline Less than 10 years & 18 & 57.4 \\
\hline 11-20 years & 27 & 2.1 \\
\hline 21-30 years & 1 & 2.1 \\
\hline 31 years and more & 1 & \\
\hline Work Experience as head of & & 36.2 \\
\hline the department (years) & & 46.8 \\
\hline less than 2 years & 17 & 6.4 \\
\hline 2-4 & 22 & \\
\hline 5-8 & 3 & \\
\hline 8 and more & & \\
\hline \hline
\end{tabular}

Source: Prepared by the researchers using the SPSS package.

\subsection{Descriptive analysis of research variables}

\subsubsection{Descriptive analysis of the independent} variable (Strategic Intelligence)

According to the appendix (2), the mean value of strategic intelligence as an independent variable is 3.56. This means that the level of strategic intelligence among academic staff higher than the average. The variable X2 (foresight helps the organization management in making effective decisions to face challenges and future variables) was more important and positive according to the opinions of the research sample because the level of their answers within the level agreed, where the mean reached 4.09 and a standard deviation of 0.503 . However, the mean value of the variable X11 (The management of the organization is keen to stimulate competition among individuals to provide great and distinguished achievements) is 3.21 , which is the last statement.

\subsubsection{Descriptive analysis of dependent variable} (Talent Management)

As shown in appendix (3), the mean value of talent management as a dependent variable is 3.354. This indicates that the level of talent management among academic staff greater than the average. The variable X16 (The management of the organization believes that human talent is the starting point for the organization's success in the present and the future at all levels.) is more important according to the research sample's opinion because the mean value is 3.74 . While the mean for variable X18 is the lowest, which represents 3.11.

Based on the results from the appendix (2 and 3), we conclude that the mean value for the research variables (strategic intelligence and talent management) is above the average, and that the general average for the standard deviation for them reflects that the dispersion of indicators is not very far apart and this reflects the positive relationship between the two variables according to calculations the sample of the research because the values of the general average for the mean approximate the level of the answer agreed and as in the following table:

Table (4): comparison between both variables according to the sample responses and according to the mean value and the standard deviation

\begin{tabular}{lll}
\hline \hline $\begin{array}{l}\text { Toverage } \\
\text { Variable }\end{array}$ & $\begin{array}{l}\text { Total averages } \\
\text { of means }\end{array}$ & $\begin{array}{l}\text { Total average of } \\
\text { standard } \\
\text { deviation }\end{array}$ \\
\hline $\begin{array}{l}\text { Strategic } \\
\text { intelligence }\end{array}$ & 3.56 & 0.938 \\
\hline $\begin{array}{l}\text { The level of } \\
\text { positivity and } \\
\text { dispersion in the positive } \\
\text { answers }\end{array}$ & $\begin{array}{l}\text { The biggest } \\
\text { Talent } \\
\text { management }\end{array}$ & Less dispersion \\
\hline $\begin{array}{l}\text { The level of } \\
\text { positivity and the } \\
\text { level of dispersion }\end{array}$ & & Less positive \\
\hline \hline
\end{tabular}

Source: Prepared by the researchers using the SPSS package.

Table (4) also explains that the independent variable (strategic intelligence) was more favorable compared to the dependent variable according to the responses of the sample members because the value of the general average for the mean was 3.354, which is greater than the value of the general average for the 
depended variable (talent management). The general standard deviation rate for strategic intelligence was less than the general average for standard deviations for talent management, and it was 0.938 .

\subsection{Proof of the validity of the research hypotheses}

4.3.1 Correlation between strategic intelligence and talent management

Table (5): Correlation analysis

\begin{tabular}{|c|c|c|c|}
\hline Variables & Correlation & $\begin{array}{l}\text { Strategic } \\
\text { intelligence }\end{array}$ & $\begin{array}{l}\text { Talent } \\
\text { management }\end{array}$ \\
\hline \multirow{3}{*}{$\begin{array}{l}\text { Strategic } \\
\text { intelligence }\end{array}$} & $\begin{array}{l}\text { Pearson } \\
\text { Correlation }\end{array}$ & 1 & $.465^{* *}$ \\
\hline & Sig. (2-tailed) & & .001 \\
\hline & $\mathrm{N}$ & 47 & 47 \\
\hline \multirow{3}{*}{$\begin{array}{l}\text { Talent } \\
\text { management }\end{array}$} & $\begin{array}{l}\text { Pearson } \\
\text { Correlation }\end{array}$ & $.465^{\star *}$ & 1 \\
\hline & Sig. (2-tailed) & .001 & \\
\hline & $\mathrm{N}$ & 47 & 47 \\
\hline
\end{tabular}

**. Correlation is significant at the 0.01 level (2-tailed).

Source: Prepared by the researchers using the SPSS package.

Table (5) reflects that the correlation coefficient value between the search variables is 0.465 . This indicates a positive correlation between strategic intelligence and talent management, proving the first primary research hypothesis's validity.

\subsubsection{Correlation between dimensions of strategic intelligence and talent management \\ Table (6): Correlation analysis}

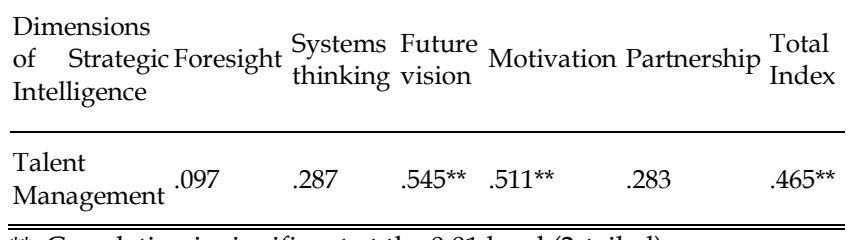

**. Correlation is significant at the 0.01 level (2-tailed).

Source: Prepared by the researchers using the SPSS package.

The outcomes of Pearson's correlation analysis are obtained for the sample and shown in table (6), there is no significant correlation between foresight and talent management $(\mathrm{r}=$.097). As a result, the first subhypothesis, H1A, has been rejected.

According to Pearson's correlation coefficient, as presented in the above table, the correlation between systems thinking is not significant .287. For that reason, the second sub-hypothesis, H1B, has been rejected.

The table (6) illustrates that future vision has the strongest relationship among strategic intelligence dimensions with talent management, representing .545. As a result, the third sub-hypothesis, H1C, has been accepted.

Besides, the correlation between motivation and talent management is significant, which reached .511 . Therefore, the fourth sub-hypothesis, H1D, has been accepted.

Finally, based on the table's results (6), there is no significant relationship between partnership and talent management $(\mathrm{r}=.283)$. As a result, the fifth subhypothesis, H1E, has been refused.

\subsubsection{The extent of the effect of strategic intelligence} on talent management

The researchers adopted in showing the degree of influence of the independent variable in the dependent variable on ANOVA analysis, as shown in table (7) as follows:

Table (7): the impact of strategic intelligence on talent management

\begin{tabular}{l}
\hline Independent \\
variable
\end{tabular}

\begin{tabular}{|c|c|c|c|c|c|c|}
\hline Dependent & & & & F & & \\
\hline variable & Beta & $\mathbf{R}^{2}$ & df & Calculated & Tabular & Sig. \\
\hline $\begin{array}{l}\text { Talent } \\
\text { management }\end{array}$ & .456 & .217 & 1,45 & 12.433 & 4.06 & .001 \\
\hline
\end{tabular}

Source: Prepared by the researchers using the SPSS package. $\mathrm{N}=47$

The results from the table (7) show that the $\mathbf{F}$ value is $(12.433)$ in $\mathbf{d f}(1,45)$ at the Sig. level $(.001)$, and the $\mathbf{R}^{\mathbf{2}}$ is $(.217)$, which means strategic intelligence explains $21.7 \%$ of the change in talent management and that the remaining $78.3 \%$ is due to other factors not included in the current research model. Therefore, we conclude that strategic intelligence has a significant impact on talent management because the calculated $\mathbf{F}$ value 
(12.433) is more significant than its tabular value (4.06).

This proves the validity of the second main research hypothesis.

\subsubsection{The impact of each dimension of strategic intelligence on talent management}

To determine the effect of each dimension of strategic intelligence on talent management and test the sub hypotheses of the second main one in some academic institutions in Duhok, the researchers relied on $(\mathrm{F})$ value and (Sig). As shown in table (8).

Table (8): the effect of each dimension of strategic intelligence on talent management

\begin{tabular}{|c|c|c|c|c|c|c|c|c|}
\hline \multirow{2}{*}{$\begin{array}{l}\text { Independent } \\
\text { Variable }\end{array}$} & \multirow{2}{*}{$\begin{array}{l}\text { Depended } \\
\text { Variable }\end{array}$} & \multirow{2}{*}{\multicolumn{2}{|c|}{${ }^{\text {Beta }} R^{2}$}} & \multirow{2}{*}{\multicolumn{2}{|c|}{ Calculated Tabula }} & \multirow{2}{*}{ Sig. } & \multirow{2}{*}{$\begin{array}{l}\text { Sub- } \\
\text { Hypotheses }\end{array}$} & \multirow[b]{2}{*}{ Decision } \\
\hline & & & & & & & & \\
\hline Foresight & $\begin{array}{l}\text { Talent } \\
\text { Management }\end{array}$ & .097 & .009 & .429 & 4.06 & .516 & $\begin{array}{l}\text { The first sub- } \\
\text { hypothesis } \\
\text { H2A }\end{array}$ & Rejected \\
\hline $\begin{array}{l}\text { Systems } \\
\text { thinking }\end{array}$ & $\begin{array}{l}\text { Talent } \\
\text { Management }\end{array}$ & .287 & .082 & 4.033 & 4.06 & .051 & $\begin{array}{l}\text { The second } \\
\text { sub-hypothesis } \\
\text { H2B }\end{array}$ & Rejected \\
\hline Future vision & $\begin{array}{l}\text { Talent } \\
\text { Management }\end{array}$ & .545 & .297 & 19.009 & 4.06 & .000 & $\begin{array}{l}\text { The third sub- } \\
\text { hypothesis } \\
\text { H2C }\end{array}$ & Accepted \\
\hline Motivation & $\begin{array}{l}\text { Talent } \\
\text { Management }\end{array}$ & .511 & .261 & 15.866 & 4.06 & .000 & $\begin{array}{l}\text { The forth sub- } \\
\text { hypothesis } \\
\text { H2D }\end{array}$ & Accepted \\
\hline Partnership & $\begin{array}{l}\text { Talent } \\
\text { Management }\end{array}$ & .283 & .080 & 3.919 & 4.06 & .054 & $\begin{array}{l}\text { The fifth sub- } \\
\text { hypothesis } \\
\text { H2E }\end{array}$ & Rejected \\
\hline
\end{tabular}

Source: Prepared by the researchers using the SPSS package. $\mathrm{df}=1,45$ $\mathrm{N}=47$

According to table (8), both sub hypotheses H2C \& H2D, have been accepted because the value of calculated $\mathrm{F}$ is greater than tabular $\mathrm{F}$ value. However, the H2A, H2B, and H2E hypotheses are rejected because the calculated $\mathrm{F}$ value is lower than its tabular value.

\section{Conclusion and recommendations}

\subsection{Conclusion}

The study has reached the following conclusion:

- Strategic intelligence is an essential starting point for supporting the talent management activities in academic institutions in Duhok city.

- The statistical analysis results indicate that the administration of academic institutions in Duhok city has an above-average level of strategic intelligence, which would enhance its ability to advance its competitive position in the future to the stage of competitive excellence in the field of higher education.

- The results show a slight weakness for the administration of academic institutions in adopting systems thinking in dealing with their immediate and future problems.

- According to the results, the future vision dimension is of great concern from the researched organizations' management in enhancing talent management.

- The researched organizations' management has an effective incentive system to support human resources towards presenting new ideas and talents.

- Educational institutions in Duhok are very interested in providing a suitable work-life to attract and maintain talents.

- The researched institutions need to develop alliance and partnership strategies with institutions working in their field to be a factor for attracting talented employees.

- The management of the academic institutions in Duhok lacks foresight and perception of what the organization will be like in the future. Therefore, it is difficult for their managers to project the present reality on what it will be in the future.

\subsection{Recommendations}

Based on the conclusions set out above, the following suggestions and recommendations can be presented:

- Paying serious and continuous attention towards strengthening and supporting administrative leaders and teaching staff from a mental perspective, such as awareness of invisible things, strategic thinking, horizon, and strategic intelligence.

- Extreme decisiveness and audacity towards the provision of human resources that possess excellent performance dimensions in terms of technical, humanitarian, and cultural terms. 
- Paying more attention to the alliance and partnership strategy to enhance expertise, expand knowledge of what to do again, and see what competitors think.

- The necessity of adopting systems thinking in analyzing phenomena and understanding their causes with holistic thought to overcome its negative consequences if they occurred or before they occurred.

- Urging, encouraging, and honoring human resources with scientific competencies and giving them a significant role in contacting customers (lecturers and students) because they are better able to influence them.

- We recommend that specialists continue to research and study in the areas of strategic intelligence and talent management, and we suggest research in:

- Analyze the relationship between strategic intelligence and new product innovation strategies.

- The role of talent management processes in organizational success.

\section{References}

1. Al-Jumaili, M. (2013). "Talent management and its reflection in enhancing the building requirements of the educated organization". A survey study of the views of a sample of academic leaders in several Iraqi universities, a master's thesis submitted to the Council of the College of Administration and Economics, Tikrit University.

2. Al-Marakhi, J. \& Al-Mahmoud, S. (2018). "Human Resource Development. An Introduction to Talent Management". An Exploratory Study behind a Sample of Administrative Leadership at Duhok Polytechnic University, Humanities Journal of Zakho University, Vol. 6, No. 3, pp. 850--869.

3. Al-Nuaimi, S. (2008). "Leading Director and Strategic Thinker, The Art and Skills of Interacting with Others". Amman, Ithraa Publishing and Distribution, $1^{\text {St }}$ edition.

4. Al-Shammari, A., Al- Mousawi, L. \& Al-Shammari, S. (2016). "The impact of talent management processes in entrepreneurial institutions". An exploratory study of the opinions of a sample of the managers of Korek Mobile Communications Company, "Al-Ghari Journal of Economic and Administrative Sciences, University of Kufa, Iraq, vol. (13) vol., No. (37),
5. Antonucci, E. J. (2005). “The leadership bench strength challenge: building integrated talent management systems". Available from Executive Development Associates. Inc at www. executive development. com.

6. Armstrong, M. (2014). "Armstrong's handbook of human resource management practice".13th ed.

7. Armstrong, M., (2009). "Strategic Human Resource Management: A guide to action". $4^{\text {th }}$ Edition, Kogan Page, Great Britain, Cambridge University Press.

8. Aston, C. \& Morton, L. (2005). "Managing talent for competitive advantage". Strategic HR Review, 4(5), 2831.

9. Bader, G. \& Lasprilla M. (2009). "Cornerstones of Successful Talent Management, What you Need to Consider When Implementing Talent Management in Your Organization". $1^{\text {st }}$ edition, Lodestone.

10. Clar, G., Acheson, H., Hafner-Zimmermann, S., Sautter, B., Buczek, M., \& Allan, J. (2008). “Strategic Policy Intelligence Tools: Enabling better RTDI policy-making in Europe's regions". Steinbeis-Edition Stuttgart/Berlin.

11. Fegley, S. (2006). "Talent management survey report". Society for Human Resources Management (SHRM) Research.

12. Fernández-Villacañas, M. (2015). “The global strategic intelligence management. Learning and thinking skills". [Online] University of Alcalá (UAH). Available at: http://europehome-project. eu/resources/learningmaterials [Accessed 14 Jul. 2016].

13. Fleisher, C. S., \& Bensoussan, B. E. (2015). “Business and competitive analysis: effective application of new and classic methods". FT press.

14. Freidberg, M., \& Kao, T. (2008). “The State of Talent Management: Today's Challenges, Tomorrow's Opportunities". Hewitt's Human Capital, 1-37.

15. Grobler, P. A., \& Diedericks, H. (2009). "Talent management: An empirical study of selected South African hotel groups". Southern African Business Review, 13(3), 1-27

16. Hughes, J. C., \& Rog, E. (2008). “Talent management: A strategy for improving employee recruitment, retention and engagement within hospitality organizations". International Journal of Contemporary Hospitality Management, 20(7), 743-757.

17. Jackson, S. E., \& Schuler, R. S. (1990). “Human resource planning: Challenges for industrial/organizational psychologists". American Psychologist,45(2), 223-239.

18. James, T., Esselaar, P., \& Miller, J. (2001). “Towards a better understanding of the ICT sector in South Africa: problems and opportunities for strengthening the existing knowledge base". Cape Town: Tina James Consulting and Miller, Esselaar and Associates. Mimeo.

19. Kuhlmann, S., Boekholt, P., Georghiou, L., Guy, K., Héraud, J. A., Laredo, P., ... \& Polt, W. (1999). "Improving distributed intelligence in complex innovation systems". Advanced Science \& Technology Policy Planning Network (ASTPP), Targeted SocioEconomic Research Program, Fraunhofer Institute Systems \& Innovation Research, Karlsruhe, June. 
20. Lewis, R. E., \& Heckman, R. J. (2006). “Talent management: A critical review". Human resource management review, 16(2), 139-154.

21. Maccoby, M. (2001). "The human side: Successful leaders employ strategic intelligence". ResearchTechnology Management, 44(3), 58-60.

22. McDowell, D. (2008). "Strategic intelligence: a handbook for practitioners, managers, and users". (Vol. 5). Scarecrow Press.

23. Nori, N. (2015). “The Impact of Strategic Intelligence on the Excellence in the Performance of Human Resources". International Conference for Human Development in Sulaymaniyah - Iraq for the period 1214 April.

24. Quarmby, N. (2003). "Futures Work in Strategic Criminal Intelligence". Paper Presented and The Evaluation In Crime \& justice: Trends \& Methods Conference Convened By The Australian Institute of Criminology in Conjunction With The Australian Bureau of Statistic, Canberra, PP: 1-10.

25. Seitovirta, L. C. (2011). “The role of strategic intelligence services in corporate decision making".

26. Service, R. (2006). "The Development of Strategic Intelligence: A Managerial Perspective". International Journal of Management, Vol.23, No.1, pp:61-77

27. Shrafman, P. (2004). "Information sharing in Support of Strategic Intelligence". Prepared For an International Conference on Countering Modern Terrorism, Current Issus \& Future Threats, Berlin.

28. Stredwick, J. (2013). “An introduction to human resource management". Routledge.

29. TETIK, S. (2017). "Talent Management: A review of theoretical perspectives and a guideline for practioners". Nile Journal of Business and Economics, 2(4), 40-56.

30. Tham, K. \& Kim, M. (2002). "Towards Strategic Intelligence With Anthology Based Enterprise Modelling". ABS Proceeding of The International Business \& Economics Research Conference, Las Vegas. NV.October7-11-.19

31. Tucker, E., Kao,T., \& Verma, N. (2005). "Nextgeneration talent management: Insights on how workforce trends are changing the face of talent management". Business Credit, 106(7), 20-27.

32. Xu, M. (2007). "Managing Strategic Intelligence: Techniques \& Technologies". United States of America \& United Kingdom, IGI Global.

33. Yusof, B. (2013). "The mechanism of alertness and strategic intelligence is a tool to face future challenges and one of the factors of competitiveness". The Fourth International Forum on Competition and Competitive Strategies of Industrial Enterprises in the Arab Countries / Faculty of Economic Sciences and Facilitation Sciences - University of Algeria. 
Academic Journal of Nawroz University (AJNU), Vol.10, No.2, 2021 


\section{Appendix (1)}

\section{Questionnaire}

\section{Dear respected respondent}

\section{Greetings,}

The questionnaire in your hands is part of the requirements for preparing the tagged research, " The Role of Strategic Intelligence in Enhancing Effective Talent Management: A Study on some Academic Institutions of Duhok Governorate," and that your favorable response contributes to obtaining accurate results to enhance achieving the research objectives, knowing that the answer is used for scientific research purposes only.

Thanks for your efforts and cooperation.

Researchers:

Araz Majeed Albarwari Sheri

Nazar Rasheed Nori

Sandeep Kumar Gupta

Note: Please put a mark $(\sqrt{ })$ in the appropriate field under the answer that expresses your opinion with sincerity and confidence.

\section{First: Personal information:}

1- Gender: Male Female

2- Age: less than 30 years 31 to 40 years 41 to 50 years 51 years and more

3- Education level: Bachelor Higher diploma Master PhD.

4- Work Experience at the university: less than 10 years 11 to 20 years 21 to 30 years years and more

5- Work Experience as head of the department: Less than 2 years $\quad 2$ to 4 years $\quad 5$ to 8 years years and more

Second: Describe the independent variable strategic intelligence

\begin{tabular}{|c|c|c|c|c|c|c|}
\hline & \multicolumn{5}{|c|}{ Weight and level of answer } \\
\hline & & \multirow{2}{*}{$\begin{array}{l}5 \\
\text { Strongly } \\
\text { Agree }\end{array}$} & \multirow{2}{*}{$\begin{array}{l}4 \\
\text { Agree }\end{array}$} & \multirow{2}{*}{$\begin{array}{l}3 \\
\text { Neutral }\end{array}$} & \multirow{2}{*}{$\begin{array}{l}2 \\
\text { Disagree }\end{array}$} & \multirow{2}{*}{$\begin{array}{l}\mathbf{1} \\
\text { Strongly } \\
\text { Disagree }\end{array}$} \\
\hline variable & Description & & & & & \\
\hline & Foresight & & & & & \\
\hline 1 & $\begin{array}{l}\text { The organization's administration is } \\
\text { exploring the future towards } \\
\text { developing college strategies in the } \\
\text { long term }\end{array}$ & & & & & \\
\hline 2 & $\begin{array}{l}\text { Foresight helps the organization's } \\
\text { management make effective decisions } \\
\text { to meet future challenges and changes. }\end{array}$ & & & & & \\
\hline 3 & $\begin{array}{l}\text { The management of the organization } \\
\text { identifies substantial opportunities in } \\
\text { which it can invest to achieve its goals. }\end{array}$ & & & & & \\
\hline & Systems thinking & & & & & \\
\hline 4 & $\begin{array}{l}\text { The adoption of systems thinking helps } \\
\text { the college administration to see the } \\
\text { events surrounding the college more } \\
\text { clearly. }\end{array}$ & & & & & \\
\hline
\end{tabular}




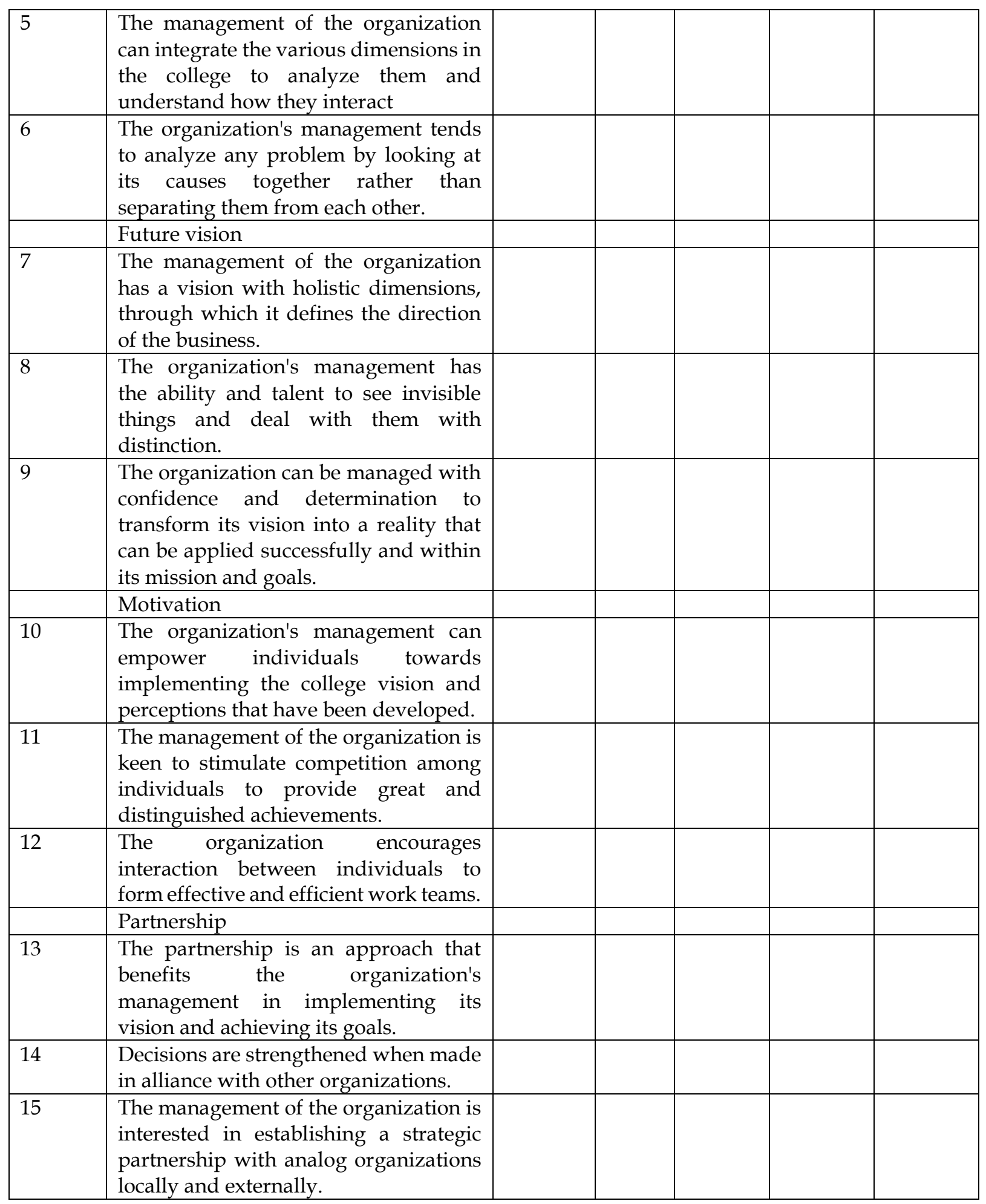

Third: Description of the dependent variable (talent management)

\begin{tabular}{|l|l|l|l|l|l|l|}
\hline \multicolumn{2}{|c|}{} & \multicolumn{3}{|l|}{ Weight and level of answer } \\
\cline { 3 - 7 } \multicolumn{2}{|l|}{} & $\mathbf{5}$ & $\mathbf{4}$ & $\mathbf{3}$ & $\mathbf{2}$ & $\mathbf{1}$ \\
\hline variable & Description & $\begin{array}{l}\text { Strongly } \\
\text { Agree }\end{array}$ & Agree & Neutral & Disagree & $\begin{array}{l}\text { Strongly } \\
\text { Disagree }\end{array}$ \\
\hline 1 & $\begin{array}{l}\text { The management of the organization } \\
\text { believes that human talent is the } \\
\text { starting point for the organization's }\end{array}$ & & & & & \\
\hline
\end{tabular}




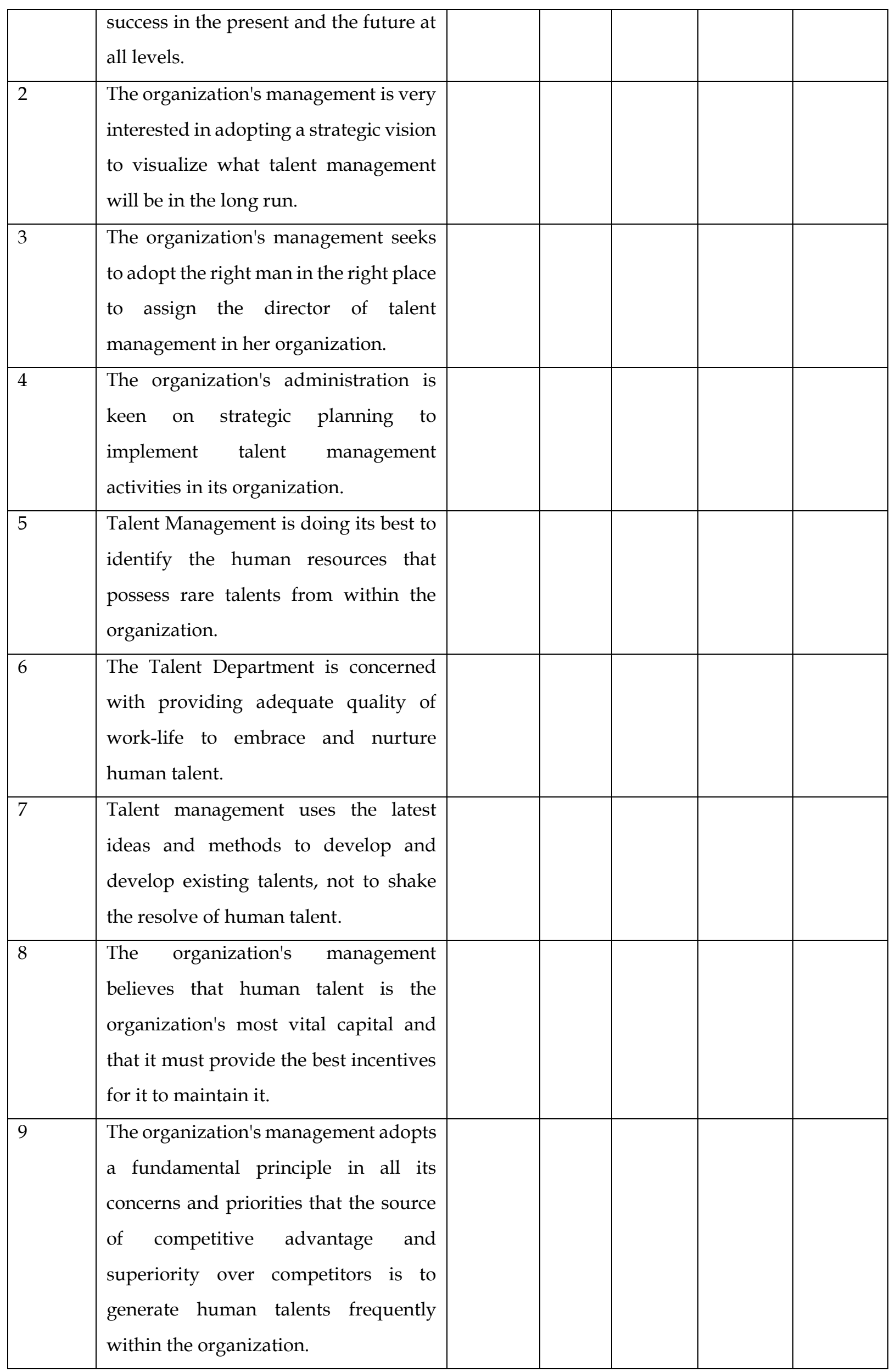




\section{Appendix (2)}

\section{Descriptive analysis of the independent variable (strategic intelligence)}

\begin{tabular}{|c|c|c|c|c|c|c|c|c|c|c|c|c|}
\hline \multirow{3}{*}{ Variables } & \multicolumn{10}{|c|}{ Evaluation Levels } & \multirow{3}{*}{ Mean } & \multirow{3}{*}{$\begin{array}{l}\text { Standard } \\
\text { deviation }\end{array}$} \\
\hline & \multicolumn{2}{|c|}{$\begin{array}{l}\text { Strongly } \\
\text { Agree }\end{array}$} & \multicolumn{2}{|c|}{ Agree } & \multicolumn{2}{|c|}{ Neutral } & \multicolumn{2}{|c|}{ Disagree } & \multicolumn{2}{|c|}{$\begin{array}{l}\text { Strongly } \\
\text { Disagree }\end{array}$} & & \\
\hline & Freq. & $\%$ & Freq. & $\%$ & Freq & $\%$ & Freq. & $\%$ & Freq. & $\%$ & & \\
\hline $\mathrm{Xa}$ & \multicolumn{10}{|c|}{ Foresight } & & \\
\hline $\mathrm{X} 1$ & 5 & $10.6 \%$ & 33 & $70.2 \%$ & 5 & $10.6 \%$ & 4 & $8.5 \%$ & 0 & 0 & 3.83 & .732 \\
\hline $\mathrm{x} 2$ & 8 & $17 \%$ & 35 & $74.5 \%$ & 4 & $8.5 \%$ & 0 & 0 & 0 & 0 & 4.09 & .503 \\
\hline $\mathrm{X3}$ & 6 & $12.8 \%$ & 22 & $46.8 \%$ & 12 & $25.5 \%$ & 7 & $14.9 \%$ & 0 & 0 & 3.57 & .903 \\
\hline Average & & & & & & & & & & & 3.83 & 0.712 \\
\hline $\mathrm{Xb}$ & \multicolumn{10}{|c|}{ Systems thinking } & & \\
\hline $\mathrm{X} 4$ & 10 & $21.3 \%$ & 24 & $51.1 \%$ & 8 & $17 \%$ & 5 & $10.6 \%$ & 0 & 0 & 3.83 & .892 \\
\hline $\mathrm{X} 5$ & 5 & $10.6 \%$ & 18 & $38.3 \%$ & 12 & $25.5 \%$ & 12 & $25.5 \%$ & 0 & 0 & 3,34 & .984 \\
\hline $\mathrm{X} 6$ & 6 & $12.8 \%$ & 21 & $44.7 \%$ & 7 & $14.9 \%$ & 13 & $27.7 \%$ & 0 & 0 & 3.43 & 1.037 \\
\hline Average & & & & & & & & & & & 3.53 & 0.971 \\
\hline $\mathrm{Xc}_{\mathrm{c}}$ & \multicolumn{10}{|c|}{ Future vision } & & \\
\hline $\mathrm{X} 7$ & 5 & $10.6 \%$ & 22 & $46.8 \%$ & 7 & $14.9 \%$ & 11 & $23.4 \%$ & 2 & $4.3 \%$ & 3.36 & 1.092 \\
\hline $\mathrm{X} 8$ & 2 & $4.3 \%$ & 22 & $46.8 \%$ & 10 & $21.3 \%$ & 11 & $23.4 \%$ & 2 & $4.3 \%$ & 3.23 & 1.005 \\
\hline X9 & 5 & $10.6 \%$ & 16 & $34 \%$ & 15 & $31.9 \%$ & 8 & $17 \%$ & 3 & $6.4 \%$ & 3.26 & 1.073 \\
\hline Average & & & & & & & & & & & 3.28 & 1.056 \\
\hline $\mathrm{Xd}$ & \multicolumn{10}{|c|}{ Motivation } & & \\
\hline $\mathrm{X} 10$ & 4 & $8.5 \%$ & 24 & $51.1 \%$ & 11 & $23.4 \%$ & 6 & $12.8 \%$ & 2 & 4.3 & 3.47 & .975 \\
\hline $\mathrm{X} 11$ & 6 & $12.8 \%$ & 16 & $34 \%$ & 10 & $21.3 \%$ & 12 & $25.5 \%$ & 3 & $6.4 \%$ & 3.21 & 1.160 \\
\hline $\mathrm{X} 12$ & 7 & $14.9 \%$ & 23 & $48.9 \%$ & 8 & $17 \%$ & 7 & $14.9 \%$ & 2 & $4.3 \%$ & 3.55 & 1.059 \\
\hline Average & & & & & & & & & & & 3.41 & 1.064 \\
\hline $\mathrm{Xe}$ & \multicolumn{10}{|c|}{ Partnership } & & \\
\hline $\mathrm{X} 13$ & 11 & $23.4 \%$ & 27 & $57.4 \%$ & 4 & $8.5 \%$ & 4 & $8.5 \%$ & 1 & $2.1 \%$ & 3.91 & .929 \\
\hline $\mathrm{X} 14$ & 15 & $31.9 \%$ & 23 & $48.9 \%$ & 7 & $14.9 \%$ & 2 & $4.3 \%$ & 0 & 0 & 4.09 & .803 \\
\hline X15 & 2 & $4.3 \%$ & 18 & $38.3 \%$ & 17 & $36.2 \%$ & 8 & $17 \%$ & 2 & $4.3 \%$ & 3.26 & .931 \\
\hline Average & & & & & & & & & & & 3.75 & 0.887 \\
\hline $\begin{array}{l}\text { Total } \\
\text { Average }\end{array}$ & & & & & & & & & & & 3.56 & 0.938 \\
\hline
\end{tabular}

Source: Prepared by the researchers using the SPSS package. 


\section{Appendix (3)}

Descriptive analysis of dependent variable (talent management)

\begin{tabular}{|c|c|c|c|c|c|c|c|c|c|c|c|c|}
\hline \multirow{3}{*}{ Variables } & \multicolumn{10}{|c|}{ Evaluation Levels } & \multirow{3}{*}{ Mean } & \multirow{3}{*}{$\begin{array}{l}\text { Standard } \\
\text { deviation }\end{array}$} \\
\hline & \multicolumn{2}{|c|}{$\begin{array}{l}\text { Strongly } \\
\text { Agree }\end{array}$} & \multicolumn{2}{|c|}{ Agree } & \multicolumn{2}{|c|}{ Neutral } & \multicolumn{2}{|c|}{ Disagree } & \multicolumn{2}{|c|}{$\begin{array}{l}\text { Strongly } \\
\text { Disagree }\end{array}$} & & \\
\hline & Freq. & $\%$ & Freq. & $\%$ & Freq. & $\%$ & Freq. & $\%$ & Freq. & $\%$ & & \\
\hline X16 & 12 & $25.5 \%$ & 21 & $44.7 \%$ & 7 & $14.9 \%$ & 4 & $8.5 \%$ & 3 & $6.4 \%$ & 3.74 & 1.132 \\
\hline $\mathrm{X} 17$ & 3 & $6.4 \%$ & 21 & $44.7 \%$ & 12 & $25.5 \%$ & 7 & $14.9 \%$ & 4 & $8.5 \%$ & 3.26 & 1.073 \\
\hline X18 & 5 & 10.6 & 13 & 27.7 & 17 & 36.2 & 6 & 12.8 & 6 & 12.8 & 3.11 & 1.165 \\
\hline X19 & 3 & 6.4 & 17 & 36.2 & 17 & 36.2 & 8 & 17 & 2 & 4.3 & 3.23 & 0.960 \\
\hline $\mathrm{X} 20$ & 6 & 12.8 & 19 & 40.4 & 9 & 19.1 & 11 & 23.4 & 2 & 4.3 & 3.34 & 1.109 \\
\hline $\mathrm{X} 21$ & 7 & 14.9 & 12 & 25.5 & 19 & 40.4 & 5 & 10.6 & 4 & 8.5 & 3.28 & 1.117 \\
\hline $\mathrm{X} 22$ & 6 & 12.8 & 19 & 40.4 & 16 & 34 & 5 & 10.6 & 1 & 2.1 & 3.51 & 0.930 \\
\hline $\mathrm{X} 23$ & 6 & 12.8 & 19 & 40.4 & 11 & 23.4 & 7 & 14.9 & 4 & 8.5 & 3.34 & 1.147 \\
\hline $\mathrm{X} 24$ & 5 & 10.6 & 20 & 42.6 & 13 & 27.7 & 6 & 12.8 & 3 & 6.4 & 3.38 & 1.054 \\
\hline $\begin{array}{l}\text { Total } \\
\text { Average }\end{array}$ & & & & & & & & & & & 3.354 & 1.076 \\
\hline
\end{tabular}

Source: Prepared by the researchers using the SPSS package. 